\title{
PENINGKATAN MANAJEMEN RISIKO KESEHATAN DAN KESELAMATAN KERJA DI TERMINAL PETI KEMAS
}

\author{
Hana Ike Dameria Purba \\ Universitas Sari Mutiara Indonesia \\ *Hana Ike Dameria Purba. Jl. Kapten Muslim No. 79 Medan, Indonesia, \\ E-mail:hanapurba29@gmail.com Phone:+6281397850898
}

\begin{abstract}
In 2018 a work accident was discovered in Container Terminal which resulted in permanent disability and a financial loss. The purpose of this study was to determine how the implementation of Occupational Health and Safety $(\mathrm{OHS})$ Risk Management in this company. This research is a qualitative research with case study research type. Data collection was done by purposive sampling. The results found that the weakness of the risk management process occurs at several stages. The company has not conducted an evaluation of the risks to determine the level of risk that cannot be tolerated. This has an impact on risk control being not focused on risks that cannot be tolerated. In addition, the risk control process carried out at container loading and unloading services only focused on improving equipment and providing PPE. Parties related to OHS have not considered management improvement which should be the main thing in improving OHS. The integration of the communication and consultation process as well as the monitoring and review in stages of determining the context, hazard identification, risk assessment and risk control were also the weaknesses in the risk management process in this company.
\end{abstract}

Keywords: containers, loading and unloading workers, risk management

\begin{abstract}
Abstrak
Pada tahun 2018 sebuah kecelakaan kerja ditemukan di Terminal Peti Kemas yang mengakibatkan cacat tetap dan kerugian finansial. Tujuan dari penelitian ini adalah untuk mengetahui bagaimana penerapan Manajemen Risiko Keselamatan dan Kesehatan Kerja (K3) di perusahaan ini. Penelitian ini adalah penelitian kualitatif dengan jenis penelitian studi kasus. Pengumpulan data dilakukan dengan purposive sampling. Hasil menemukan bahwa kelemahan dari proses manajemen risiko terjadi pada beberapa tahap. Perusahaan belum melakukan evaluasi risiko untuk menentukan tingkat risiko yang tidak dapat ditoleransi. Ini berdampak pada pengendalian risiko yang tidak berfokus pada risiko yang tidak dapat ditoleransi. Selain itu, proses pengendalian risiko yang dilakukan pada layanan bongkar muat kontainer hanya fokus pada peningkatan peralatan dan penyediaan APD. Pihak-pihak yang terkait dengan K3 belum mempertimbangkan peningkatan manajemen yang seharusnya menjadi hal utama dalam meningkatkan K3. Integrasi proses komunikasi dan konsultasi serta pemantauan dan peninjauan dalam tahapan penentuan konteks, identifikasi bahaya, penilaian risiko dan pengendalian risiko juga merupakan kelemahan dalam proses manajemen risiko di perusahaan ini.
\end{abstract}

Kata kunci: peti kemas, pekerja bongkar muat, manajemen risiko 


\section{Pendahuluan}

Pelabuhan merupakan salah satu tempat kerja yang memiliki risiko kecelakaan kerja yang cukup tinggi. Setiap tahun terjadi kecelakaan yang diakibatkan oleh pengangkatan bongkar muat di pelabuhan. Berdasarkan data statistik Marine Industrial Accident, Departemen Kelautan Hongkong tahun 2016 telah terjadi sebanyak 76 kasus kecelakaan kerja pada bagian pengangkatan bongkar muat pelabuhan. Kecelakaan kerja tersebut terdiri dari 60 kasus kecelakaan minor, 15 kasus kecelakaan serius dan 1 kasus kecelakaan fatal ${ }^{1}$.

Berdasarkan penelitian terdahulu ditemukan 5 risiko kapal menabrak dermaga menyebabkan pekerja/ tenaga kerja bongkar muat (TKBM) terpeleset, tersandung, kejatuhan benda di deck kapal, Pekerja/TKBM tertabrak RTG (Rubber Tyred Gantry) sewaktu loading/unloading, Petugas Pandu terjatuh, terjepit pada saat naik atau turun kapal dan Pekerja/TKBM tertabrak Stacker, Forklift, Side Loader sewaktu loading/unloading. Penanganan untuk risiko tinggi dengan perlakuan atas risiko berupa rencana penurunan risiko (mitigasi), menghindari risiko (Risk Avoid) dan/atau melakukan transfer risiko serta untuk risiko sedang maka perlakuannya adalah penyusunan rencana ${ }^{2}$.

Berdasarkan penelitian terdahulu mengenai penilian risiko pada pekerjaan bongkar muat di pelabuhan ditemukan bahwa terdapat 42 jenis potensi bahaya dari 8 aktivitas pada 4 tahapan pekerjaan. adapun tahapan tersebut yakni tahap persiapan, stavedoring, cargodoring, receiving/delivery. hasil penilian risiko yakni berupa 19 bahaya kategori risiko tinggi, 19 bahaya kategori risiko medium, dan 4 bahaya kategori risiko rendah. Pengendalian risiko pekerjaan bongkar muat kayu log sudah diterapkan dengan pengendalian administratif. Pengendalian administratif yang dilakukan adalah dengan sertifikasi operator alat, pelatihan K3 dan safety patrol. Pengendaliandengan APD yang sudah dilakukan yaitu pengadaan safety shoes, safety helmet dan rompi. ${ }^{3}$

Selain itu juga ditemukan ditempat lain kecelakaan kerja yang terjadi pada bongkar muat seperti putusnya tali wayer trolly RTG saat melakukan bongkar muat peti kemas yang menyebabkan tewasnya asisten operator RTG pada 21 Oktober 2017, rusaknya alat spreader, dan jatuh menimpa mobil perawatan, dan peti kemas yang merosot saat proses pengangkatan. Beberapa kejadian kecelakaan pada bongkar muat peti kemas terjadi akibat gagalnya pengoperasian alat angkat oleh operator alat tersebut ${ }^{1}$.

Hasil survei awal yang peneliti lakukan dilokasi penelitian diketahui bahwa Terminal Peti Kemas (TPK) sudah melakukan HIRARC ( Hazards Identification Risk Assessment Risk Control) dengan kata lain perusahaan tersebut sudah menerapkan Manajemen Risiko. Namun, pada tahun 2018 masih ditemukan kecelakaan kerja dibagian bongkar muat dengan kerugian 
finansial jutaan rupiah dan cacat tetap pada pekerja. Berdasarkan latar belakang dan hasil literatur review terdahulu peneliti tertarik untuk mengetahui bagaimana pelaksanaan Manajemen Risiko di TPK.

\section{Metode}

Penelitian ini merupakan penelitian kualitatif dengan jenis penelitian studi kasus yang bertujuan untuk mengetahui pelaksanaan Manajemen Risiko di TPK. Teknik pengumpulan data dalam penelitian ini dilakukan dengan purposive sampling. Informan penelitian sebanyak tiga orang dimana 2 (dua) orang merupakan tim manajemen risiko yang terlibat langsung dalam pelaksanaan manajemen risiko serta seorang asisten manajemen pelayanan operasi yang bertugas sebagai pengawas pekerja bongkar muat. Setiap informan sudah bekerja selama lebih dari 3 tahun. Sumber data dalam penelitian ini adalah dokumen identifikasi bahaya, penilaian risiko dan pengendalian risiko dan wawancara mendalam. Validasi data dalam penelitian ini menggunakan triangulasi data. Triangulasi data dilakukan dengan membandingkan hasil wawancara dengan hasil observasi lapangan terkait dengan kondisi di lapangan dan dokumen identifikasi bahaya, penilaian risiko dan pengendaliannya. Pengolahan dan analisa data dilakukan untuk menganalisis risiko kerja pada pekerja di perusahaan TPK dengan mengumpulkan semua data yang diperoleh dari wawancara, dan pengamatan di lapangan. Data yang telah terkumpul dibuat dan disusun dalam bentuk transkrip data. hasil wawancara dibuat seperti apa adanya, termasuk mencatat kembali hasil wawancara dan data rekaman. Selanjutnya akan dilakukan analisa data dan interpensi data. Kemudian, menghitung nilai risiko yang diperoleh dan hasil rating konsekuensi, paparan dan kemungkinan, sehingga diperoleh nilai risiko untuk pembanding dalam tahap penilaian tingkat risiko dalam bentuk skor. Data yang diperoleh disajikan dalam bentuk narasi dan dilengkapi dengan matriks hasil wawancara. Penyajian data akan didukung dengan hasil pengamatan lapangan.

\section{Hasil}

Informan dalam penelitian ini merupakan dua orang tim manajemen risiko yang terlibat langsung dalam pelaksanaan manajemen risiko serta seorang asisten manajemen pelayanan operasi yang bertugas sebagai pengawas pekerja bongkar muat (table 1).

Tabel 1. Karakteristik Informan

\begin{tabular}{|l|l|l|l|l|}
\hline No. & Nama & Umur & Pekerjaan & Informan \\
\hline 1. & SHO & 35 tahun & Ahli K3 & Karyawan TPK \\
\hline 2. & MTF & 50 tahun & Ahli K3 & Karyawan TPK \\
\hline 3. & SS & 45 tahun & Asmen Pelayanan Operasi & Karyawan TPK \\
\hline
\end{tabular}


Manejemen Risiko merupakan suatu usaha untuk mengetahui, menganalisis serta mengendalikan risiko dalam setiap kegiatan perusahaan dengan tujuan untuk memperoleh efektifitas dan efisiensi yang lebih tinggi. Manajemen Risiko yang diteliti adalah pelaksanaan tahapan proses manajemen risiko di TPK.

Proses penetapan konteks telah dilakukan terlebih dahulu oleh TPK sebelum melakukan indentifikasi bahaya. Adapun tahapan penetapan konteks tersebut dilakukan dengan menentukan bagian mana yang akan diidentifikasi dengan cara melakukan diskusi antara ahli K3 dengan asisten lapangan terlebih dahulu. hal-hal yang didiskusikan antara lain keadaan lapangan terkait dengan kegiatan di lapangan, kondisi peralatan yang digunakan apakah ada mengalami kerusakan atau ada yang perlu diganti. Kemudian akan dibahas kemungkinankemungkinan yang akan terjadi dan menentukan tingkat risiko tertinggi yang mungkin terjadi. Atas dasar pertimbangan inilah kemudian di tentukan pada bagian mana yang akan di Identifikasi. Biasanya hal ini di diskusikan dua kali setahun atau pada saat terjadi kecelakaan kerja. Berikut pernyataan hasil wawancara dari petugas identifikasi bahaya di TPK:

“...pertama kami diskusi dengan asisten yang ada di lapangan, kemudian kami membuat pengklasifikasian risiko yang mungkin akan terjadi di lapangan, setelah itu ditentukan mana yang paling berbahaya..."(SH)

'.... biasanya ada rapat dulu dengan tim identifikasi bahaya dengan asisten menejer lapangan, disitu yang didiskusikan tentang keadaan dilapangan, seperti membahas kondisi alat yang rusak atau yang perlu di ganti, terus kegiatan apa aja yang dilakukan di lapangan, setelah itu dipilih mana yang lebih berbahaya dan itulah yang diidentifikasi..."(SS)

“...kami itu biasanya akan mengadakan rapat dengan salah satu asisten yang ada di lapangan, karena mereka yang tau kondisi di lapangan seperti apa, setelah itu kami diskusikan lah setiap kemungkinan yang dapat terjadi dan yang paling tinggi nanti tingkat risiko itu lah yang akan kami pilih untuk di identifikasi..."(MT)

Proses identifikasi bahaya yang dilakukan di TPK dilakukan dengan cara membawa lembar berbentuk table. Adapun poin-poin yang ada pada table tersebut terdiri dari aktifitas kerja yang ada di perusahaan tersebut. Kemudian tiap aktifitas akan diidentifikasi bahayabahaya apa saja yang memungkinkan terjadi dan diisi pada kolom identifikasi bahaya. Selain itu juga ada kolom yang harus diisi seperti kejadian yang mungkin terjadi, penyebabnya, kerugian/ dampak/ kecelekaan yang mungkin terjadi. Setiap poin tersebut diuraikan dari masing-masing aktifitas dan lokasi untuk mendapatkan informasi secara spesifik. Proses identifikasi bahaya di lakukan setiap enam bulan sekali atau dua kali dalam setahun. Identifikasi bahaya juga dilakukan apabila sedang terjadi kecelakaan kemudian akan dilakukan 
pembaharuan pada daftar yang telah ada. Berikut pernyataan hasil wawancara petugas identifikasi bahaya

“..hmm untuk hal itu kami ngak melakukannya karena kami melakukan identifikasi bahaya menggunakan format kami sendiri yang sudah kami buat ..”(SH)

“... pada saat identifikasi kami sudah memiliki format yang kami buat sendiri jadi kami tidak ada lagi rapat salah satu dari kami langsung kelapanga untuk identifikasi..."(MT)

“...ngak ada lah setauku dek, karna setiap mau identifikasi bahaya udah ada dibawaknya lembar kertas identifikasinya...”(SS)

Setelah proses identifikasi bahaya dilakukan maka tahapan selanjutnya yang dilakukan adalah menghitung risiko yang terjadi. Penetapan tingkat risiko yang mungkin terjadi ditentukan berdasarkan hasil perkalian antara konsekuensi/ keparahan terjadi dengan tingkat kemungkinan kecelakaan terjadi. Berdasarkan hasil perkalian antara konsekuensi/keparahan dan kemungkinan maka akan ditentukan tingkat risiko ke dalam lima criteria yakini rendah, moderat, ekstrim dan tinggi.

TPK sudah melakukan tahapan penilain risiko. Petugas identifikasi bahaya dan ahli K3 umum mengatakan bahwa dalam penilaian risiko dilakukan sendiri oleh mereka, tetapi mengacu pada OHSAS 18001. Berikut hasil pernyataaan wawancara mereka.

“...oo itu kami juga yang buat sendiri,tapi itu kami mengacu ke yang ada di OHSAS 18001 itu nya, yang ada perkalian kemungkin terjadi sama keparahan itu tin...."(SH)

“...Maksudnya yang tabel tabel itu yaa? Yang ada warna warna itu, kalau itu kami buat sendiri juga cuman tetap kami mengacu pada peraturan yang ada...”(MT).

Sedangkan asisten manager yang dilapangan kurang mengetahui tentang penilaian risiko di TPK. Berikut pernyataan hasil wawancara dengan Asemen lapangan.

"...ehmm kalok itu aku kurang tau dek kayaknya itu bagian nya tim identifikasi bahaya nya itu dek..."(SS)

Pada tahap evaluasi risiko,tim manajemen risiko di TPK melakukan evaluasi risiko setelah melakukan pemberian pengendalian risiko seperti APD.Dengan cara menyesuaikan kembali apakah pemberian (alat pelindung diri) APD atau (alat pemadam api ringan) APAR tersebut sudah sesuai atau tidak kepada pekerja dilapangan dan didiskusikan antara tim 
manajemen risiko dengan asisten manejer (Asmen) dilapangan, evaluasi risiko juga dilakukan pada saat terjadi kecelakaan kerja .Berikut pernyataan hasil wawancara.

"... jadi gini kami itu mempunyai tahapan tersendiri, yang pertama itu identifikasi, analisa risiko, baru kami sesuaikan sama peraturan perundangannya, baru siap itu kami buat pengendalian risikonya, jadi setelah ada dulu pemberian tindakan baru kami evaluasi apakah sesuai atau tidak nya..."(SH)

"...kami ngak ada melakukan evaluasi risiko, cuman setelah kami memberikan APD sama karyawan dilapangan terus ada kecelakaan atau kejadian yang terjadi barulah kami melakukan evaluasi nya..."(MT)

"....ehmm kalok itu kami lakukan pas udah ada pemberian kek APD, atau APAR, atau perbaikan alat baru lah nanti asmen yang dilapangan rapat dengan tim identifikasi bahaya itu, untuk bicarakan sesuai tidaknya dilapangan dek...."(SS).

Berdasarkan hasil wawancara yang saya lakukan dengan tim manajemen risiko dan asisten manajener (Asemen) Lapangan mengatakan bahwa TPK sudah melakukan pengendalian risiko. Dengan cara melakukan penyesuaian dengan hasil identifikasi dan penilaian risiko, jika hasil identifikasi ekstrim maka tim manajemen risiko akan kelapangan untuk melihat secara langsung apakah perbaikan alat atau memperbaiki cara kerjanya. Sedangkan jika hasil identifikasi rendah maka tim manajemen risiko hanya akan memberikan APD. TPK juga menggunakan 5 jenis pengendalian yaitu eliminasi, subsitusi, rekayasa enginering/teknik, administratif, alat pelindung diri yang mengacu pada OHSAS 18001 dan dilakukan diskusi antara tim manajemen risiko dan asmen dilapangan .Berikut pernyataan hasil wawancara.

"...hmm kalau itu tin, pertama kami sesuaikan dulu itu sama hasil identifikasi tadi kalau dia ekstrim itu biasanya kami langsung kelapangan liat langsung apakah alat nya yang harus diganti atau cara kerjanya tapi kalau misalkan masih rendahnya risiko nya itu paling kami kasih APD aja nya tin, sama juga untuk pengendalian ini kami mengacu sama 5 elemen pengendalian itu yang eliminasi, subsitusi, terus apa lagi tin...."(SH)

"... kami itu sesuaikan dulu sama hasil penilaian risikonya setelah itu baru lah kami diskusikan pengendalian apa yang cocok, eliminasi kah atau kasih APD gitu ...."(informan 2) "...oh kalok itu biasanya ada rapat untuk bicarakan kayak kondisi alatnya terus jumlah orang yang kerja gitu gitu sih dek...."(SS).

\section{Pembahasan}

Penerapan manajemen risiko pada pekerja bongkar muat di TPK dianalisis dengan cara membandingkan dengan standar OHSAS 18001 mengenai penerapan manajemen risiko K3. Berdasarkan persyaratan OHSAS 18001 bahwa dalam hal penentuan konteks haruslah 
diselaraskan dengan visi dan misi perusahaan serta sasaran yang ingin dicapai dan berdasarkan kriteria risiko yang mungkin terjadi dalam proses pekerjaan. ${ }^{4}$

Berdasarkan formulir identifikasi bahaya yang telah ada sebelumnya, tim manajemen risiko langsung turun ke lokasi yang telah ditetapkan pada saat penetapan konteks. Pelaksanaan identifikasi bahaya hanya dilakukan sesuai dengan poin-poin yang telah di disain pada formulir identifikasi bahaya tanpa melakukan pertimbangan terkait dengan aktifitas rutin non rutin perusahaan, aktifitas individu yang memiliki akses ke tempat kerja termasuk kontraktor, perilaku manusia kondisi bahaya yang berasal dari luar perusahaan yang mungkin mengakibatkan dampak pada kesehatan dan keselamatan tenaga kerja, infrasturukur, peralatan dan material, perubahan dalam organisasi, kegiatannya atau material serta modifikasi pada system manajemen K3 yang mungkin berdampak pada aktifitas perusahaan. Hal ini menyebabkan tidak menyeluruhnya pelaksanaan identifikasi bahaya di ruang lingkup aktifitas bongkar muat perusahaan. Akibatnya peluang bahaya tidak dapat diidentifikasi secara menyeluruh. ${ }^{5}$

Pelaksanaan penilaian risiko di TPK dilakukan dengan cara penetapatan kemungkinankemungkinan terjadinya risiko dan penetapan tingkat keparahannya. Setelah penetapan tersebut dilakukan maka selanjutnya dilakukan perkalian antara tingkat kemungkinan dengan tingkat keparahannya dan hasil tersebut di kategorikan berdasarkan warna dan angka yang disusun dalam tabel. Menurut OHSAS 18001 tidak mengharuskan bahwa setiap kategori dalam tabel perkalian severity dan likelyhood harus sama dengan teori tetapi disesuaikan dengan kebutuhan yang ada di suatu organisasi. Dan TPK sudah melakukan sesuai dengan keperluan yang ada di TPK. ${ }^{6}$

OHSAS 18001 mensyaratkan untuk melakukan evaluasi risiko haruslah memperhatikan ALARP (As Low As Reasonably Practicable) yaitu tingkat risiko terendah yang masuk akal dan dapat dijalankan. ${ }^{7}$ Dan memperhatikan faktor biaya, teknologi, kepraktisan, kebiasaan, dan kemampuan dalam menjalankannya dengan konsisten dan memerlukan kajian mendalam dari berbagai aspek seperti teknis, sosial, moral, lingkungan atau perekonomian. Sedangkan TPK melakukan evaluasi hanya pada saat pengendalian sudah dilakukan tanpa memperhatikan ALARP yang merupakan factor penting dalam evaluasi risiko. Dalam tahap ini, menurut saya tim manajemen risiko di TPK memiliki persepsi yang berbeda mengenai evaluasi risiko, dikarenakan seharusnya evaluasi risiko dilakukan sesudah penilaian risiko dilakukan. ${ }^{8}$

TPK melakukan pengendalian risiko dengan cara menyesuaikan dengan hasil identifikasi dan penilaian risiko. Namun pelaksanaan pengendalian yang dilakukan di TPK 
hanya dengan penggunaan APD (Alat Pelindung Diri) untuk kategori risiko rendah. Sedangkan untuk risiko tinggi pelaksanaan pengendalian risiko dilakukan dengan pertimbangan perbaikan alat atau perbaikan cara kerja. OHSAS 18001 mensyaratkan organisasi melakukan pengendalian risiko sesuai hasil identifikasi bahaya dan penilaian risiko yang telah dilakukan. Pengendalian risiko dilakukan terhadap seluruh bahaya yang ditemukan dalam proses identifikasi bahaya dan mempertimbangkan peringkat risiko untuk menentukan prioritas dan cara pengendaliannya. Dalam menentukan pengendalian harus mempertimbangkan hirarki pengendalian mulai dari eliminasi, subsitusi, pengendalian teknis, administratif, dan penyediaan alat pelindung diri (APD).

Pelaksanaan komunikasi dan konsultasi yang dilakukan oleh pihak tim manajemen risiko dilakukan dengan dua cara yakni komunikasi internal dan komunikasi eksternal. Komunikasi internal dilakukan antara tim manajemen risiko dengan pekerja dan vendor. Adapun komunikasi tersebut berupa pelatihan, kunjungan kerja ke perusahaan yang menerapkan K3, briefing K3, safety induction, peletakan spanduk di lingkungan kerja. Sedangkan untuk komunikasi eksternal dilakukan antara tim manajemen risiko dengan disnaker dan konsultan K3. Namun pelaksanaan komunikasi tersebut tidak rutin dilakukan dan sangat jarang. Untuk pelaksanaan safety briefing hanya dilakukan satu minggu sekali. Selain itu masih kuranya informasi keselamatan dilingkungan kerja. Penginformasian keselamatan yang masih minim menyebabkan rendahnya kesadaran para pekerja untuk berprilaku aman dan selamat. ${ }^{7,9}$

\section{Kesimpulan}

Berdasarkan penelitian yang telah dilakukan dapat disimpulkan bahwa penerapan manajemen risiko pada pekerja bongkar muat di TPK terdapat perbedaan dengan persyaratan OHSAS 18001 dimana TPK tidak melakukan tahapan evaluasi sesudah penilaian risiko melainkan sesudah pengendalian risiko diberikan barulah tim manajemen risiko melakukan evaluasirisiko.

\section{Referensi}

1. Putri Sarah Alvernia, Bina Kurniawan DL. Analisis faktor-faktor yang mempengaruhi keselamatan pengoperasian alat angkat bongkar muat peti kemas (studi kasus di PT. pelabuhan tanjung priok). 2018;6.

2. Handayani NU, Sari DP, Ayuningtias DA. Analisis Risiko Bongkar Muat Petikemas di TPKS Tanjung Emas Semarang Menggunakan Metode Pairwise Comparison dan Probability Impact Analysis. 2017;2017:4-6.

3. Prasetio DB. Risk assessment pekerjaan bongkar muat di pelabuhan nusantara tanjung 
emas semarang. 2016;504-9.

4. Handayani NU, Sari DP, Irawan DO, Afdi Z. Evaluation of Implementation Readiness of ISO 31000:2009 At the Department of Industrial Engineering, University of Diponegoro. 2017;XII(1).

5. Alfatiyah R. Occupational Safety and Health Risk Management Analysis Using the Hirarc Method on Casting Workers. J Mesin Teknol (SINTEK Jurnal). 2017;11(2):88101.

6. Soputan GEM. Occupational Safety and Health (K3) Risk Management (Case Study in Building Eben Haezar High School Building). 2014;4(4):229-38.

7. Ramli S. Practical Guidelines for Risk Management in OHS OHS Risk Management Perspective. Djajaningrat H, editor. 201AD.

8. Ramli. OHSAS 18001 Occupational Safety and Health Risk Management System. husjain djajaningrat, AMAK, SKM MK, editor. Jakarta: DIAN RAKYAT; 2010. 257 p.

9. Dengan H, Requirement M, Terkait O, Perkasa BE, Perkasa E. K3 Hazard Risk Management Design Based on HIRARC Results by Fulfilling the OHSAS 18001: 2007 Reaction Regarding Clause 4.4.7 and Government Regulation No. 50 of 2012 at PT. Beton Elemenindo Perkasa. 2015;2(2):4416-23. 